\title{
研修ノート
}

音 声 検 査 の 基 本

\section{The Principle of Phonatory Function Test}

\author{
新美成二
}

声は発声機構によって外界に放出された音響現象であ る. 従って音声の検査は音としての声を対象とする検査 と, 発声機構に関する検査に分けることが出来る.

I：声を対象とした検査

声は音響現象である. 従って声の検査は, 音の物理的 な 3 つの要素, 強さ, 高さ扣よび音色について検査する ことになる. これに加えて，声の持続が大切な検査対象 となる。

\section{1）声の強さに関する検査}

発声とは空気力学的なエネルギーを音響エネルギーに 変換することである．変換された音のエネルギーは声の 強さとして知覚される. 従って声の強さに関与する要素 として, 空気力学的エネルギー, 喉頭のエネルギー変換 効率执よび声道の開放端(口)の放射特性が考えられる.

臨床的には, 呼吸器系に疾患があれば当然空気力学的 エネルギーが減少するであろらし, 喉頭に疾患があれば 変換効率は低下する.いずれの場合も声は小さくなる. つまり声が大きくなる器質的疾患は考えられない.

臨床検査としては一定の開口形態のマウスピースをく わえて, 発声させ, 一定の距離でその音圧を計測する。

大きな声が出ていない場合は, 喉頭に疾患がなければ 心理的な問題か，呼吸器系の疾患を考学るべきであろう.

2 ）声の高さに関する検査

話し声の高さ(話声位), 声の幅(生理的声域), 声区の 変換点について調べなければならない。

(1) 話声位の測定

通常の会話で最も高頻度で出現する声の高さである. 会話音声の高さは話の内容や, 話者の心理的状態によっ て著しく変わる．話声位を正しく測定しよらとすれば, 出来るだけ患者をリラックスさせ, 日常の話題について 話を引き出し, その時の声の高さを測定するのがよい。

(2) 生理的声域および声区の変換点

話声位が決定できたら，その高さから，何処まで高い 声が出せるか, 又何処まで低い声が出せるかを検査する. 気をつけなければならないのは検査しているのは生理的
声域であって, 音楽的(声楽的, 芸術的)声域ではないこ とである。知りたいのは，喉頭調節の能力であることを 忘れてはならない。成人の話声位と声域を表に示す。声 区とは同じ喉頭調節で，且つ同じょらな音色を持つ声域 を言う。地声一裏声, 胸声一頭声など様々な言われかた がされており，声区の概念はいまだ統一されていない. 生理学的には, 甲状披裂筋が優位に働いている声区(胸 声区, 地声) と輪状甲状筋が優位に働いている声区 (頭声 区，裏声)の存在は一般に認められている.

3 ）声の質に関する検査

音色は物理学的には，音波の波形である。つまり，そ の音の中に含まれる周波数成分の分布である. 従って周 波数分析をすれば評価できるはずである.しかし，音の 物理量と, 声の心理量はいまだ対応がついているとは云 いがたい. 臨床的には聴覚印象による評価を行っている. 日本音声言語医学会では嗄声を 5 つの尺度を用いて評価 する方法を推奖している５つの尺度とは嗄声の程度を 表す嗄声度 (Grade, G)，ガラガラ，ゴロゴロ·といった印 象を表す粗糙性 (Roughness, R), カサカサ，シャーシ ャ一，息漏れがするといった印象を表現する気息性 (Breathiness, B), 弱々しい, 単調な, メリハリのない といった印象を表す無力性 (Asthenicity，A), 苦しそう な，いきんだ，絞り出すょらなといら印象の努力性 (Straindness, S) である. それぞれ強く感じれば 3 , 全 く感じなければ 0 と重みづけをして表現する。

例えば G(3) R(2) B(2) A(1) S(0)のようになる. 再現 性や，検者間での一致を考えると臨床的には有用な評価 法である。

表 正常成人男女の声域扣よび話声位とを示す

\begin{tabular}{|c|c|c|c|c|}
\hline & $\begin{array}{l}\text { 声域上限（標準 } \\
\text { 偏差） }\end{array}$ & $\begin{array}{l}\text { 話声位（標準偏 } \\
\text { 差） }\end{array}$ & $\begin{array}{l}\text { 声域下限（標準 } \\
\text { 偏差） }\end{array}$ & 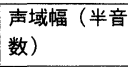 \\
\hline 成人男子 & $\mathrm{D}_{5}\left(\mathrm{Bb}_{4}-\mathrm{E}_{5}\right)$ & $C_{3}\left(B_{2}-D_{3}\right)$ & $\mathrm{CH}_{2}\left(\mathrm{Bb}_{1}-\mathrm{E}_{2}\right)$ & $37(32-43)$ \\
\hline 成人女子 & $G_{5}\left(D^{*}{ }_{5}-A_{5}\right)$ & $\mathrm{Bb}_{3}\left(\mathrm{~A}_{3}-\mathrm{C}_{4}\right)$ & $C_{3}\left(B_{2}-E_{3}\right)$ & $30(26-34)$ \\
\hline
\end{tabular}


4 ) 声の持続(最長発声持続時間)に関する検査 一息で発声できる最長の時間を最長発声持続時間 (maximum phonation time, MPT) といい音声障害の程度を 表す値としてょく用いられる．肺活量や喉頭の音声変換 の効率に依存する. 患者に出来るだけ長く声を出させて, その時間を計測するといら単純な方法である。このとき 声の高さや，強さは患者の自由にさせる，立位であって も，座位であってもよい。つまり患者の最大能力を調べ るテストであるからである，正常值は成人男子で30秒， 成人女子で 20 秒程度である。10秒以上あれば日常生活は 不自由は感じないと言われている。

\section{5 ) 音響学的検查}

計算機の普及に伴って音響分析が比較的容易に行われ るようになった。多くの音響学的パラメータが臨床的に 利用されるようになっているが，一般外来に抽いていま だ使われるに至っていない。

\section{II : 発声機構に関する検査}

音声障害診療の中で声帯振動に関する検査と空気力学

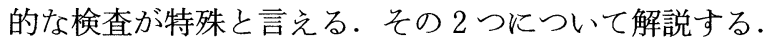

1 ) 声帯振動に関する検査

声帯振動は音源の特性を知るために大切な検査である. 一般的に行われている検査は, ストロボスコピーである. ストロボスコピーの原理を図に示す. 声帯振動周期は声 の基本周期と同じであるから，発せられた音声の基本周 期を手がかりとして閃光を発光させ観測する方法である. 観察する項目は声門閉鎖, 声帯振動の振幅, 粘膜波動の 有無, 大きさ, 左右声帯の位相の違い, 非振動部の有無 などである。どのよらな発声で観察を行ったかを記載し て扔かなければならない。

ストロボスコピーは簡便であり, 詳しく所見がとれる ので臨床的には有用な検査法であるが，原理的に運動が 規則正しいことが必要である. しかし音声障害の際の声 帯振動が規則的である保証はない，実際，高度な嗄声で はストロボの発光が声帯振動に同期しないこともよく経 験する。そのような場合は超高速度撮影法によらざるを 得ない，近年デジタル信号処理技術を用いて，比較的簡 便に超高速度による観察が可能となりつつある.

間接的に声帯振動を観察する方法として，両側声帯間 の電気的インピーダンスを計測する電気声門図 (electroglottegraphy， EGG) や声門を通過してくる光の量を 計測して声門の動態を推定する光声門図 (photoglottography，PGG) などがあるが，それぞれ一長一短あり 臨床的に使われるに至っていない。

\section{2 ) 空気力学的検查}

音声生成は空気力学的エネルギーを音響エネルギーに
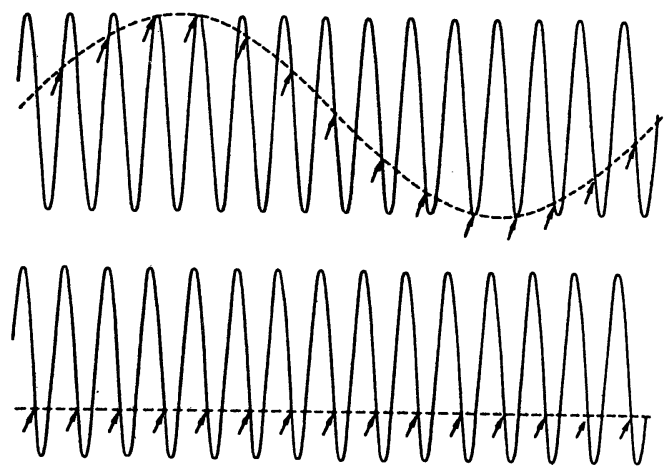

図ストロボ原理図

実線で示す規則的な現象を，矢印で示す時刻のみを観察す ると，あたかも点線のよらな現象として観察される。

変換することである. 従って空気力学的検査は音声検査 の大切な部分である。

\section{(1) 発声時呼気流率}

呼気流率を測定するのは比較的容易であり，いくつか の装置が実用に供されている。呼気流率は発声法によっ て異なる。 この特性を活かして, 発声法の検討や喉頭調 節の把握に用いられている. 正常の発声では成人男性の 平均が $101 \mathrm{ml} /$ 秒 (5\%棄却限界：46 222 $\mathrm{ml} /$ 秒) 成人 女性で $93 \mathrm{ml} /$ 秒 (同 43 197 ml/秒) と言われている.

呼気流率が大きくなる場合は声門閉鎖不全が代表的な 病態である。また，声門抵抗が低くなるような発声は器 質的な喉頭疾患がなくとも大きな呼気流率を示す. 逆に 呼気流率が小さくなるのは，声門抵抗が高い状態である。 声帯癌で声門が狭くなれば呼気流率は減少するし, 痙攣 性発声障害や過緊張性の機能性発声障害などの場合であ る.

(2) 声門下圧

喉頭に与えられる空気力学的エネルギーは呼気流と呼 気圧の積として表される. 声門下圧の測定は呼気流の測 定に比べると複雑である. 圧トランスデューサを直接声 門下に挿入する方法があるが臨床的に施行するのは困難 である。

間接的に声門下圧を推定する方法として，気流阻止法 がある．被験者にマウスピースを通して発声させ，呼気 流を短時間強制的に遮断して口腔内圧と肺内圧を平衡さ せ，その間に口腔内圧を計測する方法である。これは既 に計測装置として市販されている。

声門下圧は，呼気流率と同様で発声法や喉頭調節の状 態によって大きく異なる. 楽な発声で数 $\mathrm{cmH}_{2} \mathrm{O}$ 十数 $\mathrm{cmH}_{2} \mathrm{O}$ と考㝋てよい. 